\title{
7. Sınıf Öğrencileri Düzeyinde Duygusal Zekâ ile Çatışma Çözme Davranışı Arasındaki İlişkinin Bazı Değişkenlere Göre İncelenmesi*
}

\section{Examining the Relationship Between Emotional Intelligence and Conflict Resolution Behavior of the 7th Grade Students According to Some Variables}

\author{
Semra Kiye, ${ }^{\mathrm{a},{ }^{* *}}$ Esra Demir ${ }^{\mathrm{b}}$ \\ a Arş. Gör., Ankara Üniversitesi, Eğitim Bilimleri Fakültesi, Eğitim Bilimleri Bölümü, 06590, Ankara/Türkiye. \\ ORCID: 0000-0003-4414-5765 \\ b Dr. Öğr. Üyesi, Muş Alparslan Üniversitesi, Eğitim Fakültesi, Okul Öncesi Öğretmenliği Bölümü, 49250, Muş/Türkiye. \\ ORCID: 0000-0003-4996-0355
}

\section{MAKALE BILGİSI}

\section{Makale Geçmişi:}

Başvuru tarihi: 22 Ocak 2018

Düzeltme tarihi: 26 Şubat 2018

Kabul tarihi: 06 Mart 2018

\section{Anahtar Kelimeler:}

Duygusal Zekâ

Çatışma

Çatışma Çözme

\section{ARTICLE INFO}

\section{Article history:}

Received 22 January 2018

Received in revised form 26 February 2018

Accepted 06 March 2018

\section{Keywords:}

Emotional Intelligence

Conflict

Conflict Solving

\section{ÖZ}

Bu çalışmanın amacı yedinci sınıf öğrencileri düzeyinde duygusal zekâ ile çatışma çözme davranışı arasındaki ilişkinin bazı değişkenlere göre incelenmesidir. Araştırma ilişkisel tarama modelinde olup, araştırmanın örneklemi uygun örnekleme yöntemiyle belirlenen 2016-2017 eğitim-öğretim yılı Muş İli merkezindeki üç ortaokulda eğitim gören toplam 233 yedinci sınıf öğrencisinden oluşmaktadır. Araştırma verileri 'Kişisel Bilgi Formu', Küçükkaragöz ve Kocabaş (2012) tarafindan geliştirilen 'Çocuklar İçin Duygusal Zekâ Ölçeği' ve Koruklu (1998) tarafından geliştirilen 'Çatışma Çözme Davranışını Belirleme Ölçeği' ile elde edilmiştir. Veri analizleri için SPSS 16.0 paket programı kullanılmıștır. Elde edilen bulgulara göre duygusal zekâ ile çatıșma çözme süreçleri arasında $\mathrm{p}<0,01$ düzeyinde, pozitif yönde ve anlamlı bir ilişki vardır. Duygusal zekâları bakımından kızlar ve erkekler arasında $\mathrm{p}<0,05$ düzeyinde anlamlı bir fark saptanmıştır.

\section{A B S T R AC T}

The purpose of this study is to examine the relationship between emotional intelligence and conflict solving behavior in term of some variables at seven grade level. The relational survey approach was followed and the subjects $(n=233)$ were the seven grade students of three middle schools in Muss in the 2016-2017 academic year. Data were collected through 'Personal Information Form', 'Emotional Intelligence Scale for Children' developed by Küçükkaragöz and Kocabaş (2012) and the 'Conflict Solving Behavior Identify Scale' developed by Koruklu (1998). SPSS 16.0 package program was used for data analysis. According to the findings, there is a significant positive relationship between emotional intelligence and conflict resolution processes at $\mathrm{p}<0.01$ level. A significant difference was found at $p<0.05$ between girls and boys in terms of their emotional intelligence.

\section{Giriş}

Duygusal zekâ kavramı çok uzak bir geçmişe sahip olmamakla birlikte günümüzde birçok alanda kullanılagelen olgusal bir kavrama dönüşmüştür. Duygusal zekâ temel olarak duyguların aktif ve mantıklı bir şekilde kullanılması olarak tanımlanmakla birlikte; bireyin kendisi ve diğerlerinin duygularını anlayabilmesi, farklı duyguları ayırt edebilmesi ve bunu dile getirebilmesi, yaptığı değerlendirmeleri tutum ve davranışlarına yansıtabilmesi olarak da açıklanabilir (Hotamışlı ve Efe, 2015). Başka bir ifade ile duygusal zekâ bireyin kendisi ve diğerlerine ait duygular hakkında doğru bir algıya sahip olması; farklı duyguları ayırt edebilmesi, bunları değerlendirip ifade edebilmesi ve bunun sonucunda elde ettiklerinden davranış ve düşünce süreçlerinde faydalanması şeklindeki yetenekler olarak tanımlanabilmektedir (Salovey ve Mayer, 1990).

* Bu çalışma, 18-21 Ekim 2017 tarihlerinde Ankara'da düzenlenen 5. Uluslararası Okul Öncesi Eğitim Kongresi’nde bildiri olarak sunulmuştur.

** Sorumlu yazar/Corresponding author.

e-posta: kiyesemra@gmail.com 
Duygusal zekânın yapısını kavramsallaştırmaya yönelik birçok farklı kuramsal bakıș açısı geliştirilmiştir. Gardner 1983 'te ortaya koyduğu Çoklu Zekâ Kuramı'nda duygusal zekâ kavramını kullanmamasına rağmen kuramındaki Kişiye Dönük (Intrapersonal) ve Kişilerarası (Interpersonal) zekâ tanımları daha sonra geliştirilecek olan modellere temel oluşturmuş gibidir. Kişiye Dönük zekanın odağı bireyin kendi duygularını anlama becerisi iken Kişilerarası zekanın odağı diğer insanların duygu ve niyetlerini anlama becerisidir ( Schutte ve diğ., 1998: 168).

Duygusal zekâ kavramının tanımının ilk kez alan yazına geçmesine öncü olan bilim insanları Salovey ve Mayer (1990) olmuştur. Buna göre duygusal zekâ; bireyin kendisinin ve başkalarının duygularını izleme, bu duygular arasında ayrım yapma ve bunun sonucunda elde ettiği bilgileri düşünce ve davranışlarında rehber edinme yeteneği olarak tanımlanmıştır. Bununla beraber duygusal zekâ zihinsel bir süreç içerisindeki üç kategoriden meydana gelmektedir. Bunların ilki içerisinde bireyin ve diğerlerinin sözel ve sözel olmayan süreçlerini kapsayan duygu değerlendirme ve ifade etme kategorisi, ikincisi bireyin ve diğerlerinin duygu düzenleme süreci, üçüncüsü ise esnek planlama, yaratıcı düşünme, yeniden yoğunlaştırılan dikkat ve motivasyonu içeren duyguların kullanımı (duygulardan faydalanma) kategorisidir. Mayer ve Salovey (1997) 'in daha sonra revize ettikleri tanımları duygusal zekâyı dört boyutta ele almıştır. Bunlar; duygusal ve entelektüel gelişimi sağlayan reflektif duygu düzenleme, duygusal bilgileri kullanarak duyguları anlama ve analiz etme, düşünmenin duygusal olarak kolaylaştırılması ve son olarak duygunun algılama, değerlendirme ve ifade edilmesidir (Mayer ve Salovey. 1997'den aktaran: Schutte vd., 1998).

Duygusal zekâ konusunda Mayer ve Salovey'in modeli dişında temel olarak ön plana çıkan iki modelden (Bar-on, Goleman) daha söz edilebilir.

Bar-On' a (1997) göre duygusal zekâ, bireyin çevresinden gelebilecek her türlü zorlama ve beklentiyle başarılı bir şekilde baş edebilmesidir. Bu modelde duygusal zekâ beş boyutta ele alınmıştır. Bu boyutlar sırasıyla kişisel beceriler, kişilerarası beceriler, adaptasyon becerileri, stresle başa çıkabilme becerisi ve genel ruh durumu boyutlarıdır (BarOn, 1997'den aktaran: Acar, 2001).

Goleman 'ın duygusal zekâ modeli bireyin yeteneklerini, kişilik özelliklerini, sosyal yeterliliklerini ve motivasyonunu kapsayan bir modeldir. Buna göre duygusal zekâ bireyin kendisinin ve diğerlerinin duygularını tanıma, kendi motivasyonunu sağlama, içindeki ve çevresiyle olan ilişkilerindeki duygularını yönetebilme yetisi olarak tanımlanmaktadır (Goleman, 2009).

$\mathrm{Bu}$ model beş boyuttan oluşmaktadır. Bunlar sırasıyla; duygusal farkındalık yani kişinin duygularının farkında olması, öz-duygu yönetimi her türlü duygunun aşırı hissedilmesi durumunda bireyin kontrollü kalabilmesi, özgüdülenme bireyin tüm olumsuzluklara rağmen yılmaması, empati bireyin karşıdakinin duygularının farkında olması ve sosyal beceriler bireyin karşıdakinin duygularının farkında olarak onları kendi ilişkilerinde sorunsuz yaşamak için yönlendirebilmesidir (Goleman, 2009).

Yapılan araştırmalar insanların yaşamları boyunca başarılı ve mutlu olabilmeleri sürecinde entelektüel zekâ (IQ) gelişiminin yanı sıra duygusal zekâ (EQ) gelişiminin öneminden söz etmektedir. Hatta insanların mutluluğu için tek başına yüksek IQ'ya sahip olmanın yeterli olmadığı ifade edilmektedir. Bilim insanları bireylerin davranışlarında etkili olan duyguları anlama, duyguları ifade etme, duygulardan faydalanma ve empati kurma gibi bireyler arasındaki çatışmaları azaltan ve iletişimi arttıran duygusal özelliklerin yaşamdaki mutluluk ve başarıyı açıklamakta önemli olduklarının altını çizmektedirler (Goleman, 2009).

Çatışma kavramı olumsuz bir anlam içermekte ve uyumsuzluğun, ikircikliğin göstergesi olarak ele alınmaktadır. Çatışma iki şekilde meydana gelebilir. İlk olarak kişinin kendisiyle yaşadığı çatışma yani 'kişisel çatışmadan' söz edilebilir. Burada bireyin alternatifler içerisinden karar verememesi yani kararsız kalması anlaşılır. İkinci olarak 'ikili çatışma' kavramı karşımıza çıkmaktadır. Burada ikinci bir birey vardır ve alternatifler arasından kendi gereksinim ve ihtiyaçlarına uygun olmayanı seçmeye zorlanan birey diğer bireyle çatışma yaşar. Seçilmesi istenen alternatif bireyin gereksinimlerine ne kadar uzaksa yaratacağı gerilim de o düzeyde büyük olur. $\mathrm{Bu}$ çatışma durumunda biri diğerinden fazla olsa bile iki birey de gerilim yaşar (Başaran, 1981).

İnsanoğlu varoluşsal olarak farklı kişilik özellikleri, istek ve ihtiyaçlar, amaçlar, tercih ve değerlerin bir bütünüdür. Bütün bu değişikliklerin bir arada olduğu birbirinden farklı ortamlarda insanoğlunun çatışmalar yaşaması olasıdır hatta yaşam böyle bir süreçtir (Türnüklü ve Şahin,2002).

Johanson' ye (1997) göre çatışma yaşanması tarafların farklı ilgilere sahip olmasından kaynaklanabilir. Bireyin ilgilerine yönelmesinin engellenmesi durumu çatışma olarak ortaya çıkar bu durumda birey amaçlarına ulaşamamakta ve engellenmişlik hissetmektedir.

Dökmen'e (2012) göre bireylerarası çatışmaların nedenleri; farklı duygular, algılar, bilişler, iletişim becerileri hatta bilinçdışı süreçleri içeren kişisel özelliklerin yanı sıra toplumsal ve kültürel özellikler, bireyin sahip olduğu rollerin farklılığı ve yaşadığı sosyal-fiziksel çevre olarak değerlendirilebilir. Bununla birlikte çatışma yaratabilecek durumlar bireylerarası iletişimde karşıya verilen mesajın niteliğinden de kaynaklanabilir.

Çatışmanın tanımlanmasında belirlenebilecek ortak yönler bireyler arasında çok çeşitli ve birbirinden farklı bakış açılarının olması bununla birlikte bu farklılıkların zıtlığa ulaşmasıdır (Özdemir ve Özdemir, 2007).

Günümüz koşulları ele alındığında eğitim sistemimiz içerisinde öğrenciler, okul sürecinin belli dönemlerinde yaşamın doğal ve normal bir bileşeni olarak çatışmalar yaşamaktadırlar. Bu çatışmalar öğrenci-öğrenci çatışması olabildiği gibi öğrenci-öğretmen çatışması şeklinde de var olmaktadır (Türnüklü ve Şahin, 2002).

Çatışma yaşamda kendiliğinden var olan doğal bir süreçtir ancak çatışma sürecinin sonucunun olumlu veya olumsuz olması bireyin vereceği tepkilere bağlı olarak meydana gelir. $\mathrm{Bu}$ tepkiler bireyin kazanan ya da kaybeden pozisyonunda olmasını sağlar. Buna bağlı olarak çatışmanın yapıcı ya da yıkıcı sonuçları olabilir (Rehber, 2007).

Duygular çatışmaların vazgeçilmez bileşenleridir. Duygular, çatışma sürecini başlatacak kadar etkili olmakla birlikte 
çatışmanın olumlu bir şekilde sona ermesinde ya da derinleşmesinde de aktif rol oynarlar (Karip, 1999'dan aktaran: Atay, 2002). Ayrıca kişiler arası çatışma çözme yöntemleri arasında çatışma yaşanan bireylerin duygularını doğru anlayabilmek ve davranışlarını buna göre belirlemek ve sergilemek bulunmaktadır. Burada özellikle duygusal zekanın bileşenlerinden olan empati kurma özelliği ön plana çıkmaktadır (Rehber, 2007). Bütün bunlar ele alındığında alan yazında duygusal zekâ ile iletişim becerileri (Kayışoğlu vd., 2014 ), liderlik ilişkisi (Hotamışlı ve Efe, 2015), çatışma yönetimi (Özdemir ve Özdemir, 2007), empatik eğilim (Rehber, 2007) ve sosyal beceri düzeyi (Yurdakavuştu, 2012) konuları ele alınmaktadır. Bunların dışında da birçok farklı konu çerçevesinde araştırmaların önemsenerek sürdürüldüğü ve etkilerinin incelendiği görülmektedir. Yapılan araştırmanın da bu çerçevede duygusal zekâ ile çatışma çözme davranışları arasındaki ilişkileri göstermesi açısından alan yazına katkısının olacağı öngörülmektedir.

\section{Araştırmanın Amacı}

$\mathrm{Bu}$ çalışmanın amacı duygusal zekâ ile çatışma çözme davranışı arasındaki ilişkiyi ortaokul yedinci sınıf öğrencileri düzeyinde incelemektir. Bununla birlikte araştırmada duygusal zekâ ile çatışma çözme davranışında etkili olabileceği düşünülen cinsiyet ve sosyo-ekonomik durum değişkenleri açısından da farklılıklar incelenmiştir. Araştırmada şu sorulara cevap aranmaktadır:

(i) Ortaokul yedinci sınıf öğrencilerinin duygusal zekâları ile çatışma çözme davranışları arasında anlamlı bir ilişki var mıdır?

(ii) Cinsiyet değişkenine göre ortaokul yedinci sınıf öğrencilerinin duygusal zekâları ile çatışma çözme davranışları anlamlı derecede farklılık göstermekte midir?

(iii) Ailenin sosyo-ekonomik düzeyine göre ortaokul yedinci sınıf öğrencilerinin duygusal zekâları ile çatışma çözme davranışları anlamlı derecede farklılık göstermekte midir?

\section{Araştırmanın Yöntemi}

Duygusal zekâ ile çatışma çözme davranışı arasındaki ilişkiyi ortaokul yedinci sınıf öğrencileri düzeyinde incelemeyi amaçlayan bu araştırma ilişkisel tarama modelindedir. Tarama araştırmaları bir grubun belirli özelliklerini ortaya koymak için verilerin toplanmasını amaçlar. Araştırma konusunu herhangi bir şekilde değiştirme veya etkileme çabası gösterilmez. Önemli olan var olan durumu olduğu gibi betimleyebilmektir (Karasar, 2009).

\subsection{Evren-Örneklem}

Araştırmanın evrenini 2016-2017 eğitim-öğretim y1lında Muş İli Merkez İlçesinde ortaokul yedinci sınıfa devam eden öğrenciler oluşturmaktadır. Araştırmanın çalışma grubunu ise bu evrenden uygun örnekleme yöntemiyle seçilen üç ortaokulun yedinci sınıfinda okuyan $115 \mathrm{kız}, 118$ erkek toplam 233 kişi oluşturmaktadır. Çalışma için toplamda 250 form uygulanmış eksik veya yanlış doldurulmuş formlar çıkarıldıktan sonra 233 form değerlendirilmiştir.

\subsection{Veri toplama araçları}

Burada verilerin elde edilmesinde kullanılan araçlar hakkında bilgi verilecektir.

\subsection{1. Çocuklar İçin Duygusal Zekâ Ölçeği}

Ölçek, Küçükkaragöz ve Kocabaş (2012) tarafindan geliştirilmiştir. 4 alt boyut ve 18 maddeden oluşmaktadır. Alt boyutlar empati, duygusal zeka, motivasyon ve duyguları yönetmedir. Ölçeğin Cronbach alpha güvenirlik katsayısı 0,72 olarak saptanmıştır. Alt boyutların güvenirlik kat sayıları sirasıla empati 0,72, duygusal zeka 0,60, motivasyon 0,59 ve duyguları yönetme 0,84 olarak saptanmıştır. Ölçeğin KMO değeri ön çalışmada 0,77 olarak bulunmuştur. Ölçeğin madde toplam korelasyon sonuçları en yüksek 0,77 ve en düşük 0,50 olarak hesaplanmıştır. Faktör analizlerinden elde edilen en düşük ve en yüksek değerler ise birinci analiz için 0,66-0,80, ikinci analiz için 0,46- 0,68, üçüncü analiz için 0,46-74, dördüncü analiz için 0,46-0,76 olarak hesaplanmıştır.

\subsection{2. Çatışma Çözme Davranışını Belirleme Ölçeği}

Koruklu (1998) tarafından geliştirilen ölçek 6,7 ve 8. Sınıf öğrencilerine yöneliktir. Ölçek 2 boyut ve 24 maddeden oluşan beşli likert tipi bir ölçektir. Alt boyutlar saldırganlık ve problem çözmedir. Ölçeğin güvenirlik çalışmaları Koruklu (1998) tarafindan test tekrar test yöntemi ile değerlendirilmiş buna göre güvenirlik katsayıları saldırganlı alt boyutunda 0,64 , problem çözme alt boyutunda ise 0,66 olarak hesaplanmıştır. Ölçeğin iç tutarlılık katsayıları ise saldırganlık alt boyutu için 0,85 , problem çözme alt boyutunda 0,83 olarak hesaplanmıştır. Ölçeğin kapsam geçerliliği çalışmaları Ankara Üniversitesi Eğitimde Psikolojik Hizmetler Bölümü Psikolojik Danışmanlık ve Rehberlik alanında çalışan uzmanlardan uzman görüşü alınarak tamamlanmıştır. Faktör analizi sonucunda yapı geçerliliği iki alt boyut olarak gerçekleşmiştir. Ölçek maddelerinin madde toplam korelasyonuna bakıldığında 0,30 üzerinde olduğu belirlenmiştir.

\section{Bulgular ve Yorum}

$\mathrm{Bu}$ bölümde yapılan çalışmada elde edilen veriler çözümlenerek değerlendirilmiştir. İlk olarak öğrencilerin sosyo-demografik özelliklerine ilişkin veriler daha sonra ise yapılan veri analizleri tablolar halinde gösterilerek yorumlanıp değerlendirilecektir.

\subsection{Sosyo-Demografik Özelliklere İlişkin Bulgular}

$\mathrm{Bu}$ bölümde araştırmaya katılan öğrencilerin cinsiyetlerine ve ailelerinin ekonomik düzeyine bağlı dağılımları değerlendirilmiştir.

Tablo 1 incelendiğinde katılımcıların sosyo-demografik özelliklerinin dağılımlarına göre çalışma grubunda bulunan 233 öğrencinin $115^{\prime}$ 'i $(\% 49,35)$ k1z, $118^{\prime}$ i $(\% 50,64)$ erkektir.

Öğrencilerin ekonomik düzeyleri incelendiğinde; 6 (\% 2,57) öğrencinin düşük, 198 (\%84,97) öğrencinin yüksek, 29 $(\% 12,44)$ öğrencinin yüksek düzeye sahip olduğu görülmüştür. 
Tablo 1. Cinsiyet ve Ekonomik Düzey Dağılımları

\begin{tabular}{llcc}
\hline & & Frekans (n) & Yüzdelik (\%) \\
\hline \multirow{3}{*}{ Cinsiyet } & K1z & 115 & 49,35 \\
& Erkek & 118 & 50,64 \\
& Toplam & 233 & 100 \\
\hline \multirow{4}{*}{ Ekonomik Düzey } & Düşük & 6 & 2,57 \\
& Orta & 198 & 84,97 \\
& Yüksek & 29 & 12,44 \\
& Toplam & 233 & 100 \\
\hline
\end{tabular}

4.2. Ortaokul 7. Sinıf Öğrencilerinin Duygusal Zekâları ile Çatışma Çözme Davranışları Arasındaki İlişkilere Dair Bulgular

$\mathrm{Bu}$ kısımda elde edilen verilerin çözümlenmesiyle elde edilen bulgular açıklanacaktır. Bulguların açıklanması alt problemlerin sıralamasına bağlı olarak ve tablolarla birlikte yorumlanmıştır. İlk olarak Çocuklar İçin Duygusal Zekâ ve Çatışma Çözme Davranışını Belirleme Ölçeklerinden elde edilen verilerin normal dağılım gösterip göstermediği test edilmiştir. Verilere iliş̧kin normallik testi sonuçları Tablo 2'de verilmiştir.

Tablo 2. Normallik Testi Sonuçları

\begin{tabular}{lccc}
\hline \multirow{2}{*}{ Ölçek } & \multicolumn{3}{c}{ Kolmogorov-Smirnov } \\
& İstatistik & Sd & $\mathrm{p}$ \\
\hline Duygusal Zekâ & 0,065 & 232 & 0,019 \\
Çatı̧̧ma Çözme & 0,112 & 232 & 0,000 \\
\hline
\end{tabular}

Tablo 2'de ki sonuçlara göre, her iki ölçekten de elde edilen puanlar doğrultusunda normal dağılımın olmadığ 1 gözlenmektedir. $\mathrm{Bu}$ nedenle verilerin analizinde nonparametrik analiz yöntemleri izlenmiştir.

\subsubsection{Ortaokul Yedinci Sinif Öğrencilerinin Duygusal Zekâları İle Çatışma Çözme Davranışları Arasında Anlamlı Bir Ilişski Var Midır?}

Öğrencilerin duygusal zeka ve çatışma çözme puanları arasında bir ilişkinin olup olmadığını ortaya koymak için Spearman korelasyon analizi yapıllmıştır. Bu analize iliş̧kin sonuçlar Tablo 3 'te verilmiştir.

Tablo 3. Duygusal Zekâ Puanlarıyla Çatışma Puanları Arasındaki İlişkiyi Belirlemek Üzere Yapılan Spearman Sıra Farkları Korelasyon Analizi Sonuçları

\begin{tabular}{lcc|c}
\hline Değişken & $\mathrm{N}$ & $\mathrm{r}$ & $\mathrm{p}$ \\
\hline Duygusal Zekâ Çatışma & 233 & 0,333 & 0,000 \\
\hline
\end{tabular}

Tablo 3'e göre öğrencilerin duygusal zekâ ve çatışma çözme puan ortalamaları arasında, $\mathrm{p}<0,01$ düzeyinde, pozitif yönde anlamlı ancak orta düzeyde bir ilişki olduğu saptanmıştır ( $\mathrm{Sr}$ $=0.333, \mathrm{p}<0,01)$.

\subsubsection{Cinsiyet Değişkenine Göre Ortaokul Yedinci Sinıf Öğrencilerinin Duygusal Zekâları İle Çatışma Çözme Davranışları Anlamlı Derecede Farklılık Göstermekte Midir?}

Cinsiyet değişkenine göre ortaokul yedinci sınıf öğrencilerinin duygusal zekâları ile çatışma çözme davranışlarının anlamlı derecede farklılık gösterip göstermediğini saptamak için Mann-Whitney U Testi yapılmış olup sonuçları Tablo 4 ve Tablo 5 'te sunulmuştur.
Tablo 4. Cinsiyet Değişkenine Göre Duygusal Zekâ Ölçeği Puanları Arasındaki Farkın Anlamlılı̆̆ını Test Etmek İçin Yapılan Mann Whitney-U Testi Sonuçları

\begin{tabular}{llccccc}
\hline Ölçek & Cinsiyet & $\mathrm{N}$ & $\begin{array}{c}\text { Sira } \\
\text { Ortalaması }\end{array}$ & $\mathrm{U}$ & $\mathrm{Z}$ & $\mathrm{P}$ \\
\hline Duygusal & $\mathrm{K} 1 \mathrm{z}$ & 115 & 129,87 & 5202,000 & $-2,986$ &, 003 \\
Zekâ & Erkek & 118 & 103,58 & & & \\
\hline
\end{tabular}

Tablo 4'te görüldüğü gibi duygusal zekâları bakımından kızlar ve erkekler arasında $\mathrm{p}<0,05$ düzeyinde anlamlı bir fark saptanmıştır. Buna göre kız öğrencilerin duygusal zekâ puan ortalamalarının erkek öğrencilerin puan ortalamalarından daha yüksek olduğu ortaya çıkmıştır.

Tablo 5. Cinsiyet Değişkenine Göre Çatışma Çözme Davranışı Belirleme Ölçeği Puanları Arasındaki Farkın Anlamlılı̆̆ını Test Etmek İçin Yapılan Mann Whitney-U Testi Sonuçları

\begin{tabular}{clccccc}
\hline Ölçek & Cinsiyet & $\mathrm{N}$ & $\begin{array}{c}\text { Sira } \\
\text { Ortalaması }\end{array}$ & $\mathrm{U}$ & $\mathrm{Z}$ & $\mathrm{P}$ \\
\hline \multirow{2}{*}{ Çatışma } & $\mathrm{K}$ 'z & 115 & 118,96 & 6559.500 &,- 439 &, 661 \\
& Erkek & 118 & 115,09 & & & \\
\hline
\end{tabular}

Tablo 5'te görüldüğü gibi kız ve erkek öğrenciler arasında çatışma çözme davranışları puanlarının ortalamaları açısından $\mathrm{p}<, 05$ düzeyinde anlamlı bir fark saptanmamıştır. Buna göre bulgularımızda çatışma çözme davranışı bakımından kızlar veya erkekler arasında herhangi bir farklılık olmadığı ortaya çıkmıştır.

\subsubsection{Ailenin Sosyo-Ekonomik Düzeyine Göre} Ortaokul Yedinci Sinıf Öğrencilerinin Duygusal Zekâları İle Çatışma Çözme Davranışları Anlamlı Derecede Farklılık Göstermekte Midir?

Sosyo-ekonomik düzey değişkenine göre ortaokul yedinci sınıf öğrencilerinin duygusal zekâları ile çatışma çözme davranışlarının anlamlı derecede farklılık gösterip göstermediğini saptamak için Kruskal Wallis Testi yapılmış olup sonuçları Tablo 6 ve Tablo 7'de sunulmuştur.

Tablo 6. Duygusal Zekâ Ölçeği Puanlarının Sosyo-ekonomik Düzey Değişkenine Göre Farklılaşıp Farklılaşmadığını Belirlemek Üzere Yapılan Kruskal Wallis Testi Sonuçları

\begin{tabular}{|c|c|c|c|c|c|}
\hline Ölçek & Sosyo-Ekonomik Düzey & $\mathrm{N}$ & Ortalama Sc & $\mathrm{X}^{2}$ & $\mathrm{P}$ \\
\hline \multirow{3}{*}{$\begin{array}{l}\text { Duygusal } \\
\text { Zekâ }\end{array}$} & Düşük & 6 & 53,83 & ,610 & ,737 \\
\hline & Orta & 198 & 54,08 & & \\
\hline & Yüksek & 29 & 54,96 & & \\
\hline
\end{tabular}

Tablo 6'da görüldüğü gibi duygusal zekâ ölçeği sıralamalar ortalamalarının, öğrencilerin ekonomik düzeylerine göre anlamlı bir farklılık gösterip göstermediğini belirlemek amaciyla yapılan Kruskal Wallis testi sonucunda sosyo ekonomik düzey gruplarının sıralamalar ortalamaları arasındaki fark istatistiksel olarak anlamlı bulunmamıştır $\left(\mathrm{X}^{2}\right.$ $=0,610 ; \mathrm{sd}=2 ; \quad \mathrm{p}<.05)$. Bir başka deyişle, düşük, orta veya yüksek sosyo ekonomik düzeye sahip olmanın öğrencilerin duygusal zekâ puanları bakımından herhangi bir farklılığa sebep olmadığı saptanmıştır. 
Tablo 7. Çatışma Çözme Davranışını Belirleme Ölçeği Puanlarının Sosyo-ekonomik Düzey Değişkenine Göre Farklılaşıp Farklılaşmadığını Belirlemek Üzere Yapılan Kruskal Wallis Testi Sonuçları

\begin{tabular}{clccccc}
\hline \multirow{2}{*}{ Ölçek } & $\begin{array}{l}\text { Sosyo-Ekonomik } \\
\text { Düzey }\end{array}$ & $\mathrm{N}$ & Ortalama & $\mathrm{Sd}$ & $\mathrm{X}^{2}$ & $\mathrm{P}$ \\
\hline \multirow{2}{*}{ Çatışma } & Düşük & 6 & 76,16 & 2 & 1,481 &, 477 \\
& Orta & 198 & 79,12 & & & \\
& Yüksek & 29 & 80,55 & & & \\
\hline
\end{tabular}

Tablo 7'de görüldüğü gibi çatışma çözme davranışını belirleme ölçeği sıralamalar ortalamalarının, öğrencilerin ekonomik düzeylerine göre anlamlı bir farklılık gösterip göstermediğini belirlemek amacıyla yapılan Kruskal Wallis testi sonucunda sosyo ekonomik düzey gruplarının sıralamalar ortalamaları arasındaki fark istatistiksel olarak anlamlı bulunmamıştır $\left(\mathrm{X}^{2}=1,481 ; \mathrm{sd}=2 ; \mathrm{p}<.05\right)$. Bir başka deyişle, düşük, orta veya yüksek sosyo ekonomik düzeye sahip olmanın öğrencilerin çatışma çözme davranışları belirleme puanları bakımından herhangi bir farklılığa sebep olmadığı saptanmıştır.

\section{Sonuç ve Değerlendirme}

$\mathrm{Bu}$ araştırmada yedinci sınıf düzeyindeki öğrencilerin duygusal zekâ puanları ile çatışma çözme davranışları arasındaki ilişkiyi incelemektedir. Bunun yanı sıra duygusal zekâ puanları ile çatışma çözme davranışları bazı değişkenlere göre ele alınarak ortaya konulmaya çalışılmıştır.

Yapılan çalışmadan elde edilen bulgulara göre ortaokul yedinci sınıf öğrencilerinin duygusal zekâsı ile çatışma çözme davranışı göstermesi arasında anlamlı ancak orta düzeyde bir ilişki olduğu saptanmıştır. Çalışmamızı destekler nitelikte Atay (2002) tarafından okul müdürleriyle yapılan bir çalışmada da duygusal zekânın çatışma çözme stratejileri üzerinde etkili olduğu saptanmıştır. İki çalışma arasındaki yaş farklılığı ele ele alındığında Mayer vd. (2001) 'in araştırmasında duygusal zekâ puanlarının 13-16 yaş grubunda 18-21 yaş grubundakilere göre daha düşük olduğu dolayısıyla duygusal zekânın genç yetişkinlik döneminin başlarına kadar yaşla birlikte arttığı sonucuna ulaşılmıştır. Buna göre farklı yaş gruplarında duygusal zekânın çatışma çözme üzerindeki benzer etkililiğinden söz edilebilir. Yurtdışında yapılan bir çalışmada ise duygusal zeka ile çatışma çözme davranışı işbirliği ve uzlaşma alt boyutlarında ilişki saptanmıştır (Yu vd., 2006). Ancak duygusal zekayı beş alt boyutta değerlendiren başka bir çalışmada çatışma yönetimi ile duygusal zeka arasında kendi duygularının farkında olma, kendi duygularını yönetme boyutlarında hiçbir ilişki saptanmazken; kendini motive etme, empati, sosyal beceriler alt boyutlarında ilişki saptanmıştır (Özdemir ve Özdemir, 2007).

Duygusal zekâ puan ortalamalarına göre duygusal zekâ düzeyi kız öğrencilerde erkek öğrencilerden daha yüksek olarak saptanmıştır. Yurdakavuştu'nun (2012) yaptığı çalışmada duygusal zekânın empati ve duyguları yönetme alt boyutlarında kızlar daha yüksek puan alırken diğer alt boyutlarda fark saptanmamıştır. Topşar'ın (2015) çalışmasında ise empati ve motivasyon alt boyutlarında kızlar, duyguları yönetme alt boyutunda erkekler yüksek puana sahip ve duygusal farkındalık alt boyutunda fark yoktur. Dolayısıyla bu çalışmalara dayanarak genelde kızlar lehine bir durum olduğu ifade edilebilir. Yurtdışında yapılan çalışmalarda ise duygusal zekânın puanlarının kızlar lehine olduğu ortaya konmuştur; Austin vd. (2005), Extremera vd. (2006). Ancak Kumar ve Muniandy (2012), Kayışoğlu vd. (2014), Sevindik vd. (2012) ve İsmen'in (2004) yaptıkları çalışmada cinsiyetler arası bir fark saptanmamıştır. Dolayısıyla fark olduğu durumlarda daha ziyade kızlar lehine olumlu bir fark oluşmuştur denilebilir. Bu durum ülkemizde genel olarak kadınların duygusal ifadeleri kullanmaya daha aşina olmaları bunula birlikte erkeklerin iletişimdeki bu kolaylaştırıcıyı kullanmaya dönük rol modellerinin ve öğrenmelerinin daha yetersiz olduğu şeklinde yorumlanabilir.

Çatışma çözme davranışı gösterme durumu çalışmamızda cinsiyetlere göre farklılık göstermemiştir. Çalışmamızı destekler nitelikte; Saygılı (2010), Johnson ve Johonson, (2004) ve Gültekin'in (2006) yaptıkları çalışmalarda çatışma çözümünde cinsiyetler arası fark saptamamışlardır. Bununla birlikte yapılan başka çalışmalarda Gündoğdu (2010), Atıcı (2007), Rehber (2007), Golstein (1999) ve 11-17 yaşa arası 1655 ergenle çalışan Keltigangas-Jarvinen'in (2002) çalışmasında kızların erkeklere göre daha yüksek ortalamalara sahip oldukları saptanmıştır. $\mathrm{Bu}$ durum duygusal zekâ puanlarının kızlarda genel olarak daha yüksek olması varsayımından hareketle çatışma çözme süreçlerinde de kızların daha etkili olduklarını gösteriyor olabilir. Ancak bu konuda farklı sonuçların olduğu dikkate alındığında alan yazında daha fazla araştırmaya gerek duyulduğu şeklinde yorumlanabilir.

Duygusal zekâ ortalamaları açısından çalışmamızda sosyoekonomik düzeyler arasında herhangi bir farklılık saptanmamıştır. Erigüç vd. (2014) ile Karademir vd. (2010) çalışmaları bu çalışmanın sonuçlarını destekler niteliktedir. Ancak Yılmaz ve Özkan'ın (2011) çalışmalarında ailelerinin gelir düzeyi gider düzeyinden düşük olan öğrencilerin duygusal zekâ ortalamaları daha yüksek olarak saptanmıştır.

Çatışma çözme davranışı gösterme ortalamaları açısından çalışmamızda sosyo-ekonomik düzeyler arasında herhangi bir farklılık saptanmamıştır. Bu çalışmanın sonuçlarını destekler nitelikte olan Tümkaya ve İflazoğlu (2000), Alver (2005) ve Derin'in (2006) da ekonomik düzeyler arasında bir farklılığa rastlanmamıştır. Gündoğdu (2010) ile Rehber ve Atıcı'nın (2009) çalışmalarına göre çatışma çözme saldırganlık alt boyutunda düşük ve yüksek ekonomik düzeye sahip olanların ortalamaları orta gruptan anlamlı düzeyde yüksek olarak saptanmıştır ancak problem çözme alt boyutunda herhangi bir farklılık saptanmamıştır.

Yapılan araştırmada duygusal zekâya dönük verilerde katılımcıların daha öznel algılarla yanıtlamalarda bulunmaları bir sınırlılık olarak karşımıza çıkmaktadır. Bond ve Donaldson-Feilder (2004), duygusal zekâ konusunda bireylerin kendi kendilerine doldurdukları ölçeklerle değerlendirilmelerini başlı başına bir sınırlılık olarak görmektedirler. Onlara göre bireylerin sadece kendi algılarından hareket ederek değerlendirme yapmaları yanıltıcı olabilir.

$\mathrm{Bu}$ veriler 1şı̆̆ında şu önerilerde bulunulabilir:

(i) Yapılan diğer çalışmalarda da elde edilen benzer sonuçlar değerlendirildiğinde daha başarılı ve mutlu 
ilişkilere ulaşılabilmesi açısından okul müfredatları kapsamında programlarda sadece entelektüel zekâ değil aynı zamanda duygusal zekâ içerikli süreçler de planlanabilir.

(ii) Okul ortamlarında, sadece öğrencilere yönelik değil etkileşimlerde bütün bir personeli de içine alacak şekilde duygusal zekâ etkisinin yaygınlaştırılacağ 1 tutumların herkesçe oluşturulması önerilebilir.

(iii) Okul psikolojik danışma ve rehberlik servislerinde duygusal zekânın gelişimine dönük daha verimli sonuçlar elde etmek adına çalışmaların erken sinıflarda planlanması ve ele alınması önerilebilir.

(iv) Duygusal zekânın gelişiminde aile ortamlarının önemi ele alındığında ailelerin bu gelişim sürecindeki katılımları planlamalara dâhil edilebilir.

(v) Duygusal zekânın bileşenleri olarak kendi duygularının farkında olma ve duygularını dile getirme en fazla sorun yaşanan boyutlar olarak karşımıza çıkmaktadır. Dolayısıyla bu boyutlar üzerinde daha fazla çalışılması önerilebilir.

\section{Kaynakça}

Acar, F. T. (2001). Duygusal Zekâ Yeteneklerinin Göreve Yönelik ve İnsana Yönelik Liderlik Davranışlarl Ile Ilişkisi: Banka Şube Müdürleri Üzerine Bir Alan Araştırmast. Doktora Tezi. İstanbul: İstanbul Üniversitesi.

Acar, F. (2002). Duygusal zekâ ve liderlik. Erciyes Üniversitesi Sosyal Bilimler Enstitüsü Dergisi, 12 53-68.

Alver, B. (2005). Üniversite ögrencilerinin problem çözme becerileri ve akademik başarılarının çeşitli değişkenlere göre incelenmesi. VIII. Ulusal Psikolojik Danışma ve Rehberlik Kongresi. Marmara Üniversitesi, 21-23 Eylül, İstanbul.

Atay, K. (2002). Okul müdürlerinin duygusal zeka düzeyleri ile çatışmaları çözümleme stratejileri arasındaki ilişki. Kuram ve Uygulamada Egitim Yönetimi Dergisi, 8(3), 344-355.

Atıc1, M. (2007). Primary school students' conflict resolution strategies in Turkey. International Journal for the Advancement of Counselling, 29(2), 83-95.

Austin, E. J., Evans, P., Goldwater, R., \& Potter, V. (2005). A preliminary study of emotional intelligence, empathy and exam performance in first year medical students. Personality and Individual Differences, 39(8), 1395-1405.

Başaran, İ. E. (1981). Denetimde ikili çatışma. Ankara Üniversitesi Eğitim Bilimleri Fakültesi Dergisi,1(14), 1301-3718.

Bond, F. W., \& Donaldso-Feilder, E. J. (2004). The relative importance of psychological acceptance and emotional intelligence to workplace well-being. British Journal of Guidance \& Counselling, 32(2), 187-203.

Derin, R.(2006). İlköğretim 8. Sinıf Öğrencilerinin Problem Çözme Becerileri Ve Denetim Odağ̀ Düzeyleri Ile Akademik Başarıları Arasındaki İlişki. Yüksek Lisans Tezi. İzmir: Dokuz Eylül Üniversitesi.
Dökmen, Ü. (2012), Sanatta ve Günlük Yaşamda İletişim Çatışmaları ve Empati. İstanbul: Remzi Kitapevi.

Erigüç, G., Eriş, H., \& Kabalcıoğlu, F. (2014). Hemşirelik öğrencilerinin duygusal zeka ve iletişim becerileri: Harran üniversitesi sağlı yüksekokulu örneği. International Online Journal of Educational Sciences, 6(2), 398-412.

Extremera, N., Fernández-Berrocal, P., \& Salovey, P. (2006). Spanish version of the Mayer-Salovey-Caruso Emotional Intelligence Test (MSCEIT). Version 2.0: reliabilities, age and gender differences. Psicothema, 18, 42-48.

Gültekin, A. (2006). Psikolojik Danışmanlık Ve Rehberlik Ögrencilerinin Problem Çözme Becerilerinin Incelenmesi. Yüksek Lisans Tezi. Erzurum: Atatürk Üniversitesi.

Gündoğdu, R. (2010). 9.sınıf öğrencilerinin çatışma çözme, öfke ve saldırganlık düzeylerinin bazı değişkenler açısından incelenmesi. Ç. Ü. Sosyal Bilimler Enstitüsü Dergisi, 19(3), 257-276.

Goldstein, S. B. (1999). Construction and validation of a conflict communication scale. Journal of Applied Social Psychology, 29(9), 1803-1832.

Goleman, D. (2009). İşbaşında Duygusal Zekâ. H. Balkara (Çev.). İstanbul: Varlık Yayınları.

Hotamışlı, M., \& Efe, D. (2015). Duygusal Zekâ ve Liderlik İlişkisi Bağlamındaki Çalışmaların Bibliyometrik Analiz ile İncelenmesi. Çukurova Üniversitesi İktisadi ve İdari Bilimler Fakültesi Dergisi, 19(1), 101-121.

İşmen, A. E. , (2004). Duygusal Zeka ve Aile İşlevleri Arasındaki İlişki. Balıkesir Üniversitesi Sosyal Bilimler Enstitüsü Dergisi, 7(11), 55-75.

Johnson, D. W. (1993). Reaching out: Interpersonal effectiveness and self-actualization. Allyn \& Bacon.

Johnson, D. W., \& Johnson, R. T. (2004). Implementing the" Teaching Students To Be Peacemakers Program". Theory into practice, 43(1), 68-79.

Karademir, T., Döşyılmaz, E., Çoban, B., \& Kafkas, M. E. (2010). Beden eğitimi ve spor bölümü özel yetenek sınavına katılan öğrencilerde benlik saygısı ve duygusal zeka. Kastamonu Eğitim Dergisi, 18(2), 653-674.

Karasar, N. (2009). Bilimsel Araştırma Yöntemi. Ankara: Nobel Yayın Dağıtım.

Kayışoğlu, N. B., Doğan, İ., \& Çetin, M. (2002). Gençlik Kampı Lider Adaylarının Duygusal Zekâ Düzeyleri ve İletişim Becerilerinin İncelenmesi. Ankara Üniversitesi Spor Bilimleri Fakültesi Dergisi, 12(1), 43-50.

Keltikangas-Jarvinen, L. (2002). Aggressive problemsolving strategies, aggressive behaviour and social acceptance in early and late adolescence. Journal of Youth and Adolescence, (34), 279-287.

Koruklu, N. (1998). Arabuluculuk Eğitiminin İlköğretim Düzeyindeki Bir Grup Öğrencinin Çatışma Çözme Davranışlarına Etkisinin Incelenmesi. Yüksek Lisans Tezi. Ankara: Ankara Üniversitesi. 
Kumar, J. A., \& Muniandy, B. (2012). The Influence of Demographic Profiles on Emotional Intelligence: A Study on Polytechnic Lecturers in Malaysia. International Online Journal of Educational Sciences, $4(1), 62-70$.

Küçükkaragöz, H., \& Kocabaş, A. (2012). Çocuklar Iç̧in Duygusal Zeka Ölçeğinin İlköğretim 5. Sinıf Öğrencilerinde Geçerlik ve Güvenirliği. 11. Ulusal Sınıf Öğretmenliği Eğitimi Sempozyumu. 24-26 Mayıs 2012. Recep Tayyip Erdoğan Üniversitesi, Rize.

Mayer, J. D., Perkins, D. M., Caruso, D. R., \& Salovey, P. (2001). Emotional intelligence and giftedness. Roeper Review, 23(3), 131-137.

Özdemir, A.Y., \& Özdemir, A. (2007). Duygusal zekâ ve çatışma yönetimi stratejileri arasındaki ilişkilerin incelenmesi: Üniversitede çalışan akademik ve idari personel üzerine uygulama. Selçuk Üniversitesi Sosyal Bilimler Enstitüsü Dergisi, (18), 393-410.

Rehber, E., \& Atıcı, M. (2009). İlköğretim ikinci kademe öğrencilerinin empatik eğilim düzeylerine göre çatışma çözme davranışlarının incelenmesi. Ç. Ü. Sosyal Bilimler Dergisi, 18(1), 323-342.

Rehber, E. (2007). İlköğretim Íkinci Kademe Öğrencilerinin Empatik Eğilim Düzeylerine Göre Çatışma Çözme Davranışlarının İncelenmesi. Yüksek Lisans Tezi. Adana: Çukurova Üniversitesi.

Salovey, P.. \& Mayer, J. D. (1990). Emotional intelligence. Imagination, Cognition and Personality, 9, 185-211.

Sayg1l, H. (2000). Problem Çözme Becerisi İle Sosyal Ve Kişisel Uyum Arasındaki İlişkinin İncelenmesi. Yüksek Lisans Tezi. Erzurum: Atatürk Üniversitesi.

Sevindik, F., Uncu, F., \& Dağ, D. G. (2012). Sağlik yüksekokulu öğrencilerinin duygusal zekâ düzeylerinin bazı değişkenler açısından incelenmesi. Fırat Üniversitesi Să̆llk Bilimleri Tıp Dergisi, 26(1), 21-26.

Schutte, N. S., Malouff, J. M., Hall, L. E., Haggerty, D. J., Cooper, J. T., Golden, C. J., \& Dornheim, L. (1998). Development and validation of a measure of emotional intelligence. Personality and individual differences, 25(2), 167-177.

Topşar, A. (2015). Ortaokul 7. Sınıf Öğrencilerinde Duygusal Zekâ İle Bilgisayar Oyun Bağımlılı̆̆ı Arasındaki İlişkinin İncelenmesi. Yüksek Lisans Tezi. İstanbul: Fatih Üniversitesi.

Tümkaya, S., \& İflazoğlu, U. A. (2000). Ç Ü Sınıf Öğretmenliği Öğrencilerinin Otomatik Düşünce ve Problem Çözme Düzeylerinin Bazı Sosyo Demografik Değişkenlere Göre İncelenmesi. Çukurova Üniversitesi Sosyal Bilimler Enstitüsü Dergisi, 6(6), 143-158.

Türnüklü, A., \& Şahin, A. G. İ. (2002). İlköğretim okullarında öğrenci çatışmaları ve öğretmenlerin bu çatışmalarla başaçıkma stratejileri. Kuram ve Uygulamada Ĕ̈itim Yönetimi, 30(30), 283-302.

Yılmaz, E., \& Özkan, S. (2011). Hemşirelik öğrencilerinin duygusal zekâ düzeylerinin bazı değişkenler açısından incelenmesi. Maltepe Üniversitesi Hemșirelik Bilim ve Sanatı Dergisi, 4(1), 39-52.

Yu, C. S., Sardessai, R. M., Lu, J., \& Zhao, J. H. (2005). Relationship of emotional intelligence with conflict management styles: an empirical study in China. International Journal of Management and Enterprise Development, 3(1-2), 19-29.

Yurdakavuştu, Y.(2012). İlköğretim Öğrencilerinde Duygusal Zekâ Ve Sosyal Beceri Düzeyi. Yüksek Lisans Tezi. İzmir: Dokuz Eylül Üniversitesi. 